\title{
Brasilia tapaculo (Scytalopus novacapitalis) seasonality and site occupancy in altitudinal riparian environments after non-natural burnings and feral pig invasion in Serra da Canastra National Park, Brazil
}

\author{
I. L. D. Cunha $a^{a^{*}}$ (D), M. G. Reis ${ }^{a}$ (D), C. Z. Fieker ${ }^{a}$ (D) and M. M. Dias ${ }^{a}$ \\ aLaboratório de Aves Neotropicais, Departamento de Ecologia e Biologia Evolutiva, Programa de Pós-Graduação em \\ Ecologia e Recursos Naturais, Universidade Federal de São Carlos - UFSCar, Rod. Washington Luís, Km 235, SP-310, \\ São Carlos, SP, Brasil \\ *e-mail: isa1dc@hotmail.com
}

Received: May 14, 2019 - Accepted: November 13, 2019 - Distributed: May 31, 2021

(With 3 figures)

\begin{abstract}
The Brasilia Tapaculo, Scytalopus novacapitalis Sick, 1958, is a rare, geographically restricted, and endangered bird species that inhabits riparian vegetation of Cerrado, mainly Gallery Forests. In Serra da Canastra National Park, southeastern Brazil, wetlands are under threat due to frequent non-natural burnings and invasion by feral pigs, Sus scrofa, Linnaeus, 1758. We aimed to evaluate the possible effects of seasonal variations on S. novacapitalis records in undisturbed habitats and answer questions about how fire and feral pigs may affect site occupancy of the species. Transects alongside riparian environments were used to survey $n=21$ sites, totalizing $7.5 \mathrm{Km}$, from 2014 to 2019. Results indicated the season influenced both, spontaneous records and induced encounters by playback method, which were more abundant in breeding period, from early spring to summer. The use of playback significantly increased the amount of records in all seasons. The probability of site occupancy in all studied area was higher in late spring $(\psi=0.91)$ and lower in autumn $(\psi=0.73)$. In burned sites $(n=8)$, the first post-fire month showed the lowest probability of occupancy, but there was a rapid recovery in $2^{\text {nd }}$ month and stabilization similar to control area from the $3^{\text {rd }}$ month ahead. After sites $(n=11)$ were invaded by feral pigs, the estimation of site occupancy indicated a slight drop in first two months, but after the $3^{\text {rd }}$ month of invasion the decreasing pattern enhanced the discrepancy with undisturbed areas. It is important to keep monitoring S. novacapitalis population and their threats, to subsidize management actions, especially to avoid frequently unusual burnings in riparian forests, and to block the access of feral pigs to wetlands.
\end{abstract}

Keywords: Gallery Forest, wetlands, fire, Sus scrofa, biological invasion.

\section{Sazonalidade do Tapaculo-de-Brasília (Scytalopus novacapitalis) e ocupação de área em ambientes ripários de altitude após queimadas não naturais e invasão por javaporco no Parque Nacional da Serra da Canastra, Brasil}

\begin{abstract}
Resumo
O tapaculo-de-Brasília, Scytalopus novacapitalis Sick, 1958, é uma espécie de ave rara, geograficamente restrita e ameaçada de extinção que habita vegetação ripária do Cerrado, principalmente matas de galeria. No Parque Nacional da Serra da Canastra, sudeste do Brasil, áreas úmidas estão ameaçadas devido a frequentes queimadas não naturais e a invasão por javaporco, Sus scrofa Linnaeus, 1758. Avaliamos os possíveis efeitos da sazonalidade na quantidade de registros de $S$. novacapitalis em habitats sem perturbação e buscamos responder questões sobre como o fogo e a invasão por javaporco pode afetar a ocupação de área pela ave. Transecções paralelas aos ambientes ripários foram usadas para amostrar $\mathrm{n}=21$ áreas, totalizando $7,5 \mathrm{~km}$, de 2014 a 2019. Os resultados indicaram que a estação do ano influenciou na quantidade de registros espontâneos e de registros induzidos por playback, os quais foram mais abundantes durante o período reprodutivo. $\mathrm{O}$ uso de playback aumentou significativamente a quantidade de registros em todas as estações. A probabilidade de ocupação considerando toda área de estudo foi maior no fim da primavera $(\psi=0,91)$ e menor no outono $(\psi=0,73)$. Em áreas queimadas ( $\mathrm{n}=8$ trechos), o primeiro mês após o fogo apresentou a menor probabilidade de ocupação, mas houve uma rápida recuperação no $2^{\circ}$ mês, e estabilização similar na área controle a partir do $3^{\circ}$ mês. Após $n=11$ trechos terem sido invadidos por javaporcos, a estimativa de ocupação de área indicou pequena queda nos dois primeiros meses, mas a partir do $3^{\circ}$ mês, o padrão de decréscimo ampliou a discrepância com áreas não perturbadas. É importante continuar monitorando a população de $S$. novacapitalis e suas ameaças, para subsidiar ações de manejo, principalmente para evitar queimadas não naturais frequentes nas florestas ripárias e bloquear o acesso de javaporcos às áreas úmidas.
\end{abstract}

Palavras-chave: Mata de Galeria, áreas úmidas, fogo, Sus scrofa, invasão biológica. 


\section{Introduction}

Riparian environments are transition zones between terrestrial and aquatic ecosystems, characterized by singular vegetation established alongside rivers, streams, lakes and water springs, including forests and open vegetation (Naiman and Décamps, 1997; Barbosa, 2001). Those environments offer resources and adequate conditions for both, aquatic and terrestrial biological communities (Pusey and Arthington, 2003; Lima and Zakia, 2004). In Cerrado phytogeographic domain, riparian vegetation plays an important role as natural corridor for fauna and for plant seed dispersing (Silva and Bates, 2002). Also, the unique characteristics of wetlands vegetation, contrasting to the dry grasslands, savannas and non-wet forests, favor the presence of habitat-dependent species (Bagno and Marinho-Filho, 2001; Fieker et al., 2013).

Natural occurrence of wildfires in Cerrado is expected in fire-prone ecosystems, mainly open vegetation physiognomies such as grasslands and savannas (Mistry, 1998), and have the potential to significantly alter the structure of biological communities (Reis et al., 2016). However, anthropogenic burnings had become common due to human activities with potential arson risk (Pivello, 2011), and has been reaching wetlands with higher frequencies (Oliveira et al., 2014).

Among many other threats, wet vegetations in Cerrado have been suffering with exotic species. One of the most destructive invasive species in Neotropics is the feral pig, Sus scrofa Linneus, 1758 (Quintela et al., 2010). This exotic species showed a strong potential to cause severe alterations in understory vegetation and soil of forests (Hegel and Marini, 2013).

Serra da Canastra National Park harbors a huge bird diversity, with many rare, threatened, migratory and ecological relevant species (Silveira, 1998; IBAMA, 2005; Bessa et al., 2011; Fieker et al., 2014). This protected area has priority for the conservation of Neotropical birds, according to Birdlife International (Wege and Long, 1995), and is an IBA, Important Bird Area of the Cerrado domain (Bencke et al., 2006). In last decades, large-scale burnings occurring out of the expected natural period of wildfires, has been the main threat to Serra da Canastra ecosystems (Medeiros and Fiedler, 2004; França, 2010; Magalhães et al., 2011), and frequently reaches non-pyrophytic ecosystems, such as Gallery Forests (Reis, 2015; Souza et al., 2017). Additionally, the wetlands of Serra da Canastra National Park are under invasion by feral pigs, which have reached altitudinal portions of this conservation unit in the last years (Ribeiro, P.V. and the staff of Serra da Canastra National Park, pers. comm.).

The Brasilia Tapaculo, Scytalopus novacapitalis Sick, 1958 (Aves: Rhinocryptidae), is a rare bird, geographically restricted to central Brazil highlands, between Brasilia - Federal District, and southwestern Minas Gerais state, mainly in Serra da Canastra region (Krabbe and Schulenberg, 2019). The species is endangered, and its global population is declining due to habitat loss and alteration, however, it is little known and there is lack of data on basic aspects of species populations (Birdlife International, 2018; Krabbe and Schulenberg, 2019). We aimed to investigate the seasonality influence on S. novacapitalis encounters and possible change of site occupancy in areas under different impacts, trying to answer the following questions: (i) Does season influence number of encounters with birds? (ii) How fire affected site occupancy? (iii) How the invasion of feral pigs has been changing patterns of habitat occupation by $S$. novacapitalis?

\section{Material and Methods}

\subsection{Study area}

Serra da Canastra is a geographical landform characterized by a group of mountains with plain plateaus at the top. The National Park includes most of altitudinal tableland areas of the mountain range, however, less than a half of its 200,000-ha legal area is in fact legitimated as a protection unit. Plateaus are between 1200 m-1450 m above sea level, standing out from neighboring areas of about $700 \mathrm{~m}$ - $900 \mathrm{~m}$ (IBAMA, 2005). The climate is Cwb according to Köppen classification, with a rainy summer, and cold and dry winter (Alvares et al., 2013).

Located in southeastern Brazil, Minas Gerais state, the Serra da Canastra National Park (SCNP) protects the largest contiguous remnants of natural grasslands in the southern Cerrado morphoclimatic and phytogeographical domain (Sano et al. 2010), distributed mainly in altitudinal plateaus (IBAMA, 2005). In those tablelands, open physiognomies are dominant, such as typical grasslands ("campo limpo"), rocky grasslands ("campo rupestre"), grasslands with soil mounds ("campos de murundu"), wet grasslands ("campo úmido"), and open savannas ("campo sujo", "campo cerrado", "parque cerrado"). Forests and dense vegetation are restricted to riparian environments, as the Gallery Forests and riparian forests ("mata de galeria", "mata ripária"), and very small forest patches in wet soils associated to water spring ("capão de mata") (IBAMA, 2005; Fieker et al., 2014).

The study area comprises five watercourses in high portions of the mountaintops, located in "Chapadão da Canastra” plateau (central coordinates: 20¹3'51.52”S, $46^{\circ} 29^{\prime} 11.39^{\prime \prime} \mathrm{W}$ ), ranging from $1250 \mathrm{~m}$ to $1400 \mathrm{~m}$ of altitude. We focused on riparian ecosystems along watercourses with an average width of $\bar{x}=1.78 \mathrm{~m}( \pm 0.89 \mathrm{~m})$, where we established 21 transects, each one parallel to a river stretch, considered as a sampling site as detailed in Table 1. Those areas are mainly surrounded by dry grasslands, so the transition between riparian vegetation and the landscape matrix is abrupt.

\subsection{Field survey}

Scytalopus novacaptalis is known to be restricted to riparian ecosystems and, as other family members of same genus, it is a photophobic species (Vielliard, 1990; Sick, 1997). Its mouse-like behavior, small size $(11 \mathrm{~cm})$, and foraging habits in shadowed understory of forests are strongly restrictive for visual encounters. Thus, we 
Table 1. Characteristics of sampling sites along riparian environments of five watercourses in altitudinal plateau of Serra da Canastra National Park. Sampling effort in undisturbed areas were applied in all sampling sites; and in disturbed areas, applied only in sites burned or invaded by feral pigs, during five months after the occurrence or beginning of disturbances.

\begin{tabular}{|c|c|c|c|c|c|c|c|c|c|c|}
\hline \multirow[b]{2}{*}{ 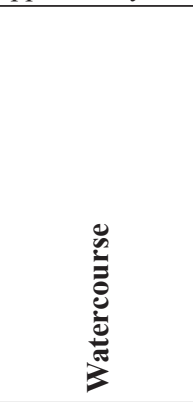 } & \multirow[b]{2}{*}{ 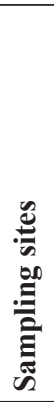 } & \multirow[b]{2}{*}{ 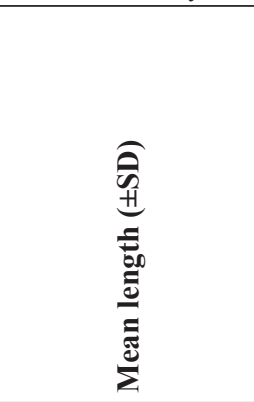 } & \multirow[b]{2}{*}{ 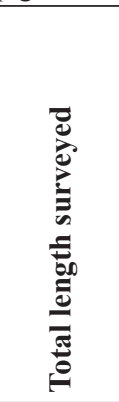 } & \multirow[b]{2}{*}{ 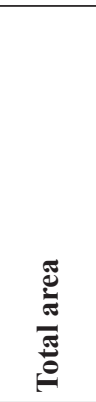 } & \multicolumn{2}{|c|}{$\begin{array}{c}\text { Undisturbed } \\
\text { areas }\end{array}$} & \multicolumn{4}{|c|}{ Disturbed areas } \\
\hline & & & & & 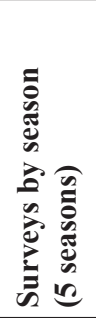 & 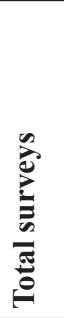 & 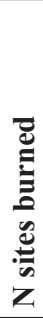 & 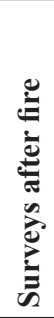 & 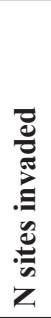 & 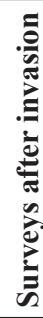 \\
\hline Peixe River & 5 & $408 \mathrm{~m}( \pm 44 \mathrm{~m})$ & $2.1 \mathrm{~km}$ & 8 ha & 6 & 30 & 1 & 20 & - & - \\
\hline $\begin{array}{c}\text { São Francisco } \\
\text { River }\end{array}$ & 6 & $379 \mathrm{~m}( \pm 27.1 \mathrm{~m})$ & $2.2 \mathrm{~km}$ & $6.7 \mathrm{ha}$ & 6 & 30 & 1 & 20 & 3 & 20 \\
\hline $\begin{array}{l}\text { S. Francisco } \\
\text { tributary A }\end{array}$ & 2 & $404.5 \mathrm{~m}( \pm 13.4 \mathrm{~m})$ & $0.81 \mathrm{~km}$ & 3 ha & 6 & 30 & - & - & - & - \\
\hline $\begin{array}{l}\text { S. Francisco } \\
\text { tributary B }\end{array}$ & 4 & $224 \mathrm{~m}( \pm 19.8 \mathrm{~m})$ & $0.88 \mathrm{~km}$ & 4 ha & 5 & 25 & 3 & 20 & 4 & 20 \\
\hline $\begin{array}{l}\text { Sto. Antônio } \\
\text { tributary }\end{array}$ & 4 & $373.2 \mathrm{~m}( \pm 15.2 \mathrm{~m})$ & $1.49 \mathrm{~km}$ & $4.2 \mathrm{ha}$ & 5 & 25 & 3 & 20 & 4 & 20 \\
\hline Total: & 21 & - & $7.5 \mathrm{~km}$ & 26 ha & & & 8 & & 11 & \\
\hline
\end{tabular}

SD: standard deviation. N: number.

designed the field study to firstly access the patterns of spontaneous encounters (auditive and/or visual), and then induce individuals to acoustic response and/or visual contact using the playback method, indicated for cryptic and elusive birds (Marion et al., 1981; Vrezec and Bertoncelj, 2018).

We surveyed the selected areas walking in pre-defined transects (Bibby et al., 2000) alongside riparian environments (Table 1), since they are linear ecosystems with small width, where we recorded the number of individual encounters in each site and season, without and with playback. We first walked each site always at the same pace (about $2 \mathrm{Km} / \mathrm{h}$ ) without any intervention, and then we return broadcasting the $S$. novacapitalis vocalization. The sampling sequence of transects was randomized. It is possible to distinguish the number of individuals vocalizing, and two individuals at the same site were the maximum number recorded during surveys in transects, as other authors have noticed before (e.g., Silveira, 1998). So, we were able to use both, abundance and presence/absence data for statistical procedures.

The field study focused on seasonality and site occupancy in undisturbed areas was conducted from April 2016 to March 2019. We organized samples in five seasonal periods, with a division in spring surveys to consider territoriality changes due to breeding period. Early spring comprised field campaigns from the end of September to October; late spring: December; summer: February and March; autumn: April and May; winter: July and August.

Samples from disturbed areas were collected in established sampling sites after the occurrence of unusual burnings ( 8 sites) and feral pig confirmed invasion (11 sites). In both situations, we performed 4 surveys by month, from the $1^{\text {st }}$ to the $5^{\text {th }}$ month after the disturbance, totalizing 20 samples from each site (Table 1). Fire is an ecological factor in open Cerrado, but not usual during winter (the peak of dry season, without weather conditions to generate lightning strikes), nor in riparian environments (Mistry, 1998; Reis et al., 2016). We focused on anthropogenic burnings occurred in the winter of different years, at distinct river stretches (group of sites). Some sites could not be sampled sequentially in the first burning, so the data from distinct burning events were gathered according to post-fire month ( $1^{\text {st }}$ to $5^{\text {th }}$ month), ranging from August or early September ( $1^{\text {st }}$ post-fire months) to January or early February ( $5^{\text {th }}$ post-fire months), from 2014 to 2018 , according to the fire event. In the case of feral pigs, records in SCNP started in 2014 (Ribeiro, P.V. and the staff of Serra da Canastra National Park, pers. comm.), but we noticed their presence high in the plateau, nearby studied river stretches, in spring of 2017. In the end of 2018, feral pigs reached 11 study sites, so we performed surveys from December/2018 to April/2019.

We selected as control samples the surveys in the same sites, carried out in previous years in the case of invasion by feral pigs, or other years in sites without records of burnings for more than 18 months. Control samples were limited to the same number of samples in the same seasonal period (of other years), to allow comparisons and to avoid seasonality influence in activity patterns of $S$. novacapitalis.

\subsection{Statistical analysis}

We performed a chi-square test $\left(\chi^{2}\right)$ using spontaneous records as observed events and records after the playback as expected values, since they can be considered closer to 
the actual number of individuals in the studied sites during surveys. The analysis of variance (one-way ANOVA) was run in both types of records, with and without playback, considering five seasons and five watercourses. We used Shapiro-Wilk test to verify the normality (Zar, 1999). Results were significant for $\alpha=0.05$. These statistical procedures were performed in PAST Program (Hammer et al., 2001), version 3.23, released in April 2019.

Presence or absence of $S$. novacapitalis in sampling sites in each survey were used to indicate the state of occupation throughout seasons (all data), in each season, and in each month after disturbance, aiming to estimate the site occupancy probability $(\psi-p s i)$ and the probability of detect the species when they are present in surveyed areas $(\mathrm{P}-r h o)$. For those estimations, we used the statistical procedure applied in models presented by Mackenzie et al. (2002), proposed to estimate by continuous surveys the proportion of area occupied by a species in situations that are not guaranteed to be detected, even when present in the studied area during a given survey.

We selected multi-season (or dynamic) model using presence-absence data from all seasonal surveys in undisturbed areas, which considers changes in state of occupancy throughout seasons (Mackenzie et al., 2002).
We also run the single-season model using data from each month after disturbance, considering that $\psi$ and $\mathrm{P}$ parameters are closed to changes during the survey. These statistical procedures were run in program Presence (Hines, 2006), version 2.12.22, released in 2018 .

\section{Results}

We obtained $n=143$ spontaneous individual records during the first part of each sample, and $n=318$ records after the playback, about 2.2 times more encounters with Scytalopus novacapitalis. The number of records in all seasons (Figure 1) were significantly improved by the playback method $\left(\chi^{2}=100.76, \mathrm{DF}: 4, p<0.001\right)$.

Individual encounters were more frequent during the reproductive period, mainly in the late spring (Figure 1). Seasonality influenced the number of records for both, spontaneous $(\mathrm{F}=4.708, p=0.007)$ and induced vocalizations by playback $(\mathrm{F}=3.81, p=0.018)$.

The probability of site occupancy considering all sites throughout seasons was $\psi=0.77$ and the probability of species being detected when present was $\mathrm{P}=0.49$ (Figure 2). Estimations in autumn indicated the lowest occupancy probability $(\psi=0.73)$, and late spring, the highest $(\psi=0.91)$.

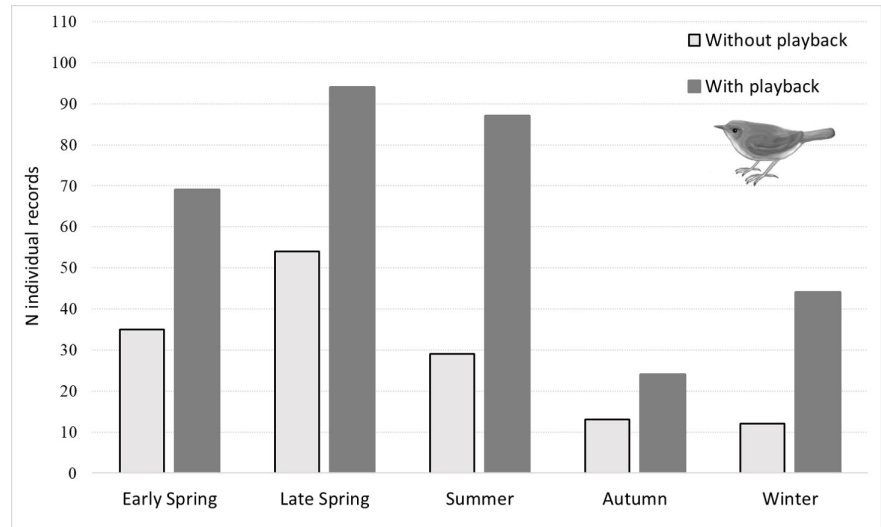

Figure 1. Number of individual records of the Brasilia Tapaculo (Scytalopus novacapitalis) during seasonal surveys in both situations, spontaneous encounters (without playback) and induced encounters (with playback), in Serra da Canastra National Park.

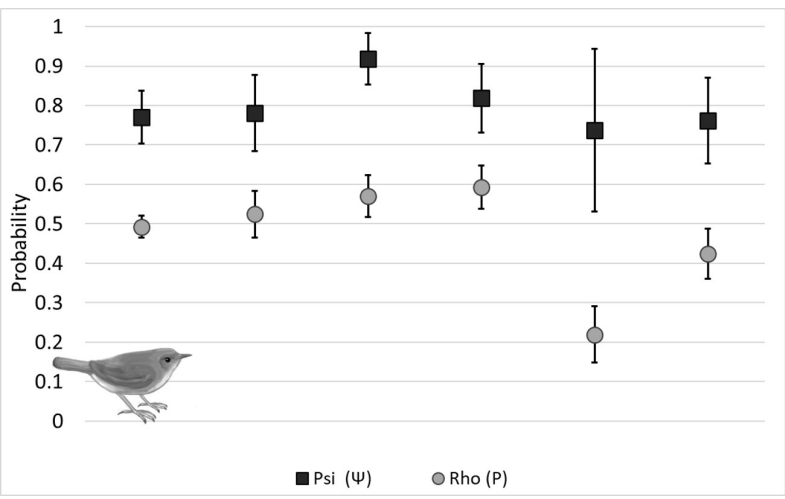

Figure 2. Estimations of site occupancy probability, psi $(\psi)$, and the probability of record the Brasilia Tapaculo (Scytalopus novacapitalis) when present in the area during the survey, rho $(\mathrm{P})$. 


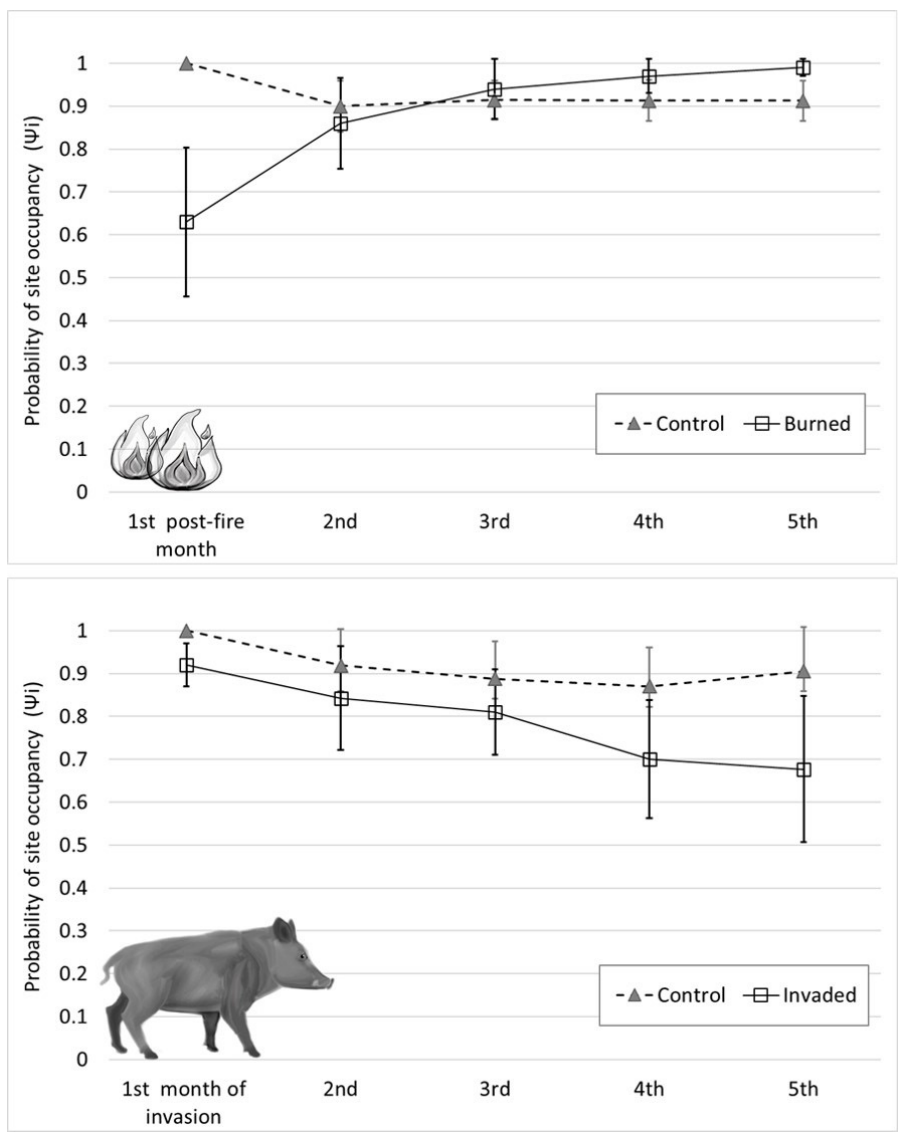

Figure 3. Estimations of site occupancy probability, psi $(\psi)$, by the Brasilia Tapaculo (Scytalopus novacapitalis) in undisturbed areas (control) compared to sites affected by burnings (above) and invaded by feral pigs (below) in Serra da Canastra National Park.

During autumn season, the chance of detecting S. novacapitalis individuals when they are present in sampling sites was the lowest (Figure 2), corroborating previous analysis that seasonality influences bird activities.

Areas affected by unusual burnings had the lowest probability of occupancy by $S$. novacapitalis after a month (Figure 3$)$. However, the recovery of $p s i(\psi)$ values occurred after two months and the stabilization after the third month, coinciding with the breeding period and rainy season.

Sites recently invaded by feral pigs exhibited values of occupancy by $S$. novacapitalis lower but close to the same months in same months of previous years (Figure 3). Even considering the expected decrease of $\psi$ due to seasonal influence (as seem in Figure 2), it is possible to note in Figure 3 a rapid reduction in occupancy probability throughout time in invaded sites, reaching $\psi=0.71$ in the fifth month.

\section{Discussion}

The Brasilia tapaculo (Scytalopus novacapitalis) prove to be a very elusive bird, considerably hard to find without playback. Silveira (1998) has stated they are easily attracted by playback in riparian forests of Serra da Canastra plateaus, a characteristic confirmed in the present study.
Also, the author said that one or two individuals can be found at most stretches of riparian vegetation and small patches of forests surrounding water springs ("capão de mata"), as we saw during surveys. Ad libitum observations on behavior during breeding period indicated the pairs of individuals recorded together or very near in the same sampling site tend to be couples, but also one adult with a juvenile, observed in rare occasions.

Seasonality exerts influence on the number of individual records, both without and with playback, considering the five seasons defined in this study. For many Neotropical bird species, the rainy season in Cerrado (from October to March), which comprises the solar seasons spring and summer in the Southern Hemisphere, coincides with breeding period, leading to pronounced changes in behavioral repertoire (Sick, 1997). Thus, it is expected to notice more individual spontaneous records due to reproductive behavior and/or area defense, and more behavioral responses to call-broadcast due to territorialism (Stutchbury and Morton, 2008). Beyond seasonality effects identified by statistical analysis, the results seeing through a behavioral perspective suggest that $S$. novacapitalis is a very territorial species (higher number of records after playback and during breeding season), and indicated the 
possibility of using vocalization for other purposes than area defense, e.g., for reproduction or communication between pairs (more spontaneous records of two individuals in each site during breeding period).

Unusual non-natural burnings caused a severe decrease of occupancy in the first month, indicating the bird dependence on understory vegetation, the most affected stratum of the forests. Herbs, sedges, grasses, small and midsize bushes, bromeliads, epiphytes (of all strata), and the litter layer of dead leaf and other parts of plants that reaches over $10 \mathrm{~cm}$ depth in many points, suffered harder with burnings, practically disappearing in many sites. However, the recovery of psi $(\psi)$ values occurred after two months, and the stabilization after the third month, coinciding with the breeding period and rainy season.

This result does not prove $S$. novacapitalis is adapted to fire events in wetlands, as other birds of Cerrado can be since they inhabit fire-prone ecosystems, mostly open areas, e.g., dry grasslands and savannas (Reis et al., 2016; Machado et al., 2017). However, results indicated the studied population used an effective strategy that guaranteed a rapid return and occupation of sites after burnings. It is plausible to think that the individuals had temporarily moved to non-burned or less-burned riparian vegetation stretches. Therefore, huge fire events affecting large areas could cause a worrisome scenario, very different from what we observed in this study, that could lead to local extinction of the bird due to lack of refugees in undisturbed sites.

Burned areas ( $\mathrm{n}=8$ sites) represented $38.1 \%$ of all studied sites, and riparian stretches invaded and constantly accessed by feral pigs comprised $52.4 \%$. Considering the overlap of sites affected by both disturbances, $57.14 \%$ of the studied sites have suffered from some type of disturbance in different times. Since all burned sites were recovered in terms of site occupancy by $S$. novacapitalis when feral pigs stablished in the area, it is not possible to evaluate what consequences a double impact at the same time on riparian ecosystems could inflict in Scytalopus novacapitalis population. Nevertheless, it is important to monitoring ecological impacts on riparian environments to be alert when two types of disturbances affect the same area.

The fieldwork stopped after the fifth month of feral pig invasion. However, results indicated a noteworthy decrease pattern in habitat occupation that should be monitored, to be ready to rapidly implement adequate environmental management actions in invaded areas. Aiming the conservation of $S$. novacapitalis, a native, endangered, rare, and geographically restricted species endemic to wet forests of central Brazil highlands, feral pigs must not access riparian environments or any wetlands, the less common ecosystem type regarding land cover in the plateaus of Serra da Canastra National Park.

\section{Acknowledgements}

We thank CAPES for doctoral scholarship to I.L.D Cunha and C.Z. Fieker, CNPq for doctoral scholarship to M.G. Reis, and ICMBio for the research authorizations (SISBIO n. 36905 and n. 58430). We are grateful to Paola V. Ribeiro and the Serra da Canastra National Park staff for field support. We also thank Dr. Sávio F. Bruno, Dra. Sônia Buck, Dr. Marcelo A. Fernandes, the anonymous reviewers, and the editorial board of Brazilian Journal of Biology for the valuable suggestions.

\section{References}

ALVARES, C.A., STAPE, J.L., SENTELHAS, P.C., MORAES GONÇALVES, J.L. and SPAROVEK, G., 2013. Köppen's climate classification map for Brazil. Meteorologische Zeitschrift (Berlin), vol. 22, no. 6, pp. 711-728. http://dx.doi.org/10.1127/09412948/2013/0507

BAGNO, M.A. and MARINHO-FILHO, J., 2001. A avifauna do Distrito Federal: uso de ambientes abertos e florestais e ameaças. In: J.F. RIBEIRO, C.E.L. FONSECA and J.C. SOUSA-SILVA, eds. Cerrado: caracterização e recuperação de matas de galeria. Planaltina: Embrapa, pp. 495-528.

BARBOSA, L.M., 2001. Considerações gerais e modelos de recuperação de formações ciliares. In: R.R. RODRIGUES and H.F. LEITÃO-FILHO. Matas ciliares: conservação e recuperação. São Paulo: Editora da Universidade de São Paulo, pp. 289- 310.

BENCKE, G.A., MAURÍCIO, G.N., DEVELEY, P.F. and GOERCK, J.M., 2006. Áreas Importantes para a Conservação das Aves no Brasil. Parte I - Estados do Domínio da Mata Atlântica. São Paulo: Editora SAVE Brasil.

BESSA, R., PARRINI, R., ABDALA, A., KIRWAN, G.M., PIMENTEL, L. and BRUNO, S.F., 2011. Novos registros ornitológicos para a região da Serra da Canastra, Minas Gerais, Brasil. Cotinga, vol. 33, pp. 94-101.

BIBBY, C.J., BURGESS, N.D., HILL, D.A. and MUSTOE, S.H., 2000. Bird census techniques. 2nd ed. USA: Academic Press, 302 p.

BIRDLIFE INTERNATIONAL, 2018. Scytalopus novacapitalis. The IUCN Red List of Threatened Species. Cambridge: International Union for Conservation of Nature and Natural Resources, pp. e.T22703531A131361562. http://dx.doi.org/10.2305/IUCN. UK.2018-2.RLTS.T22703531A131361562.en.

FIEKER, C.Z., REIS, M.G. and BRUNO, S.F., 2014. Guia de bolso: 100 aves do Parque Nacional da Serra da Canastra-MG. São Roque de Minas: ICMBio, 124 p.

FIEKER, C.Z., REIS, M.G. and DIAS-FILHO, M.M., 2013. Structure of bird assemblages in dry and seasonally flooded grasslands in Itirapina Ecological Station, São Paulo state. Brazilian Journal of Biology = Revista Brasileira de Biologia, vol. 73, no. 1, pp. 91-101. http://dx.doi.org/10.1590/S1519-69842013000100011. PMid:23644792.

FRANÇA, H., 2010. Os incêndios de 2010 nos Parques Nacionais do Cerrado. São Paulo: Universidade Federal do ABC. Relatório técnico.

HAMMER, Ø., HARPER, D.A.T. and RYAN, P.D. , 2001. PAST: paleontological statistics software package for education and data analysis. Palaeontologia Electronica, vol. 4, no. 1, pp. 1-9.

HEGEL, C.G.Z. and MARINI, M.Â., 2013. Impact of the wild boar, Sus scrofa, on a fragment of Brazilian Atlantic Forest. Neotropical Biology and Conservation, vol. 8, no. 1, pp. 17-24. 
HINES, J.E., 2006. PRESENCE- software to estimate patch occupancy and related parameters, vers.2.12.22. Maryland: USGS-PWRC.

INSTITUTO BRASILEIRO DO MEIO AMBIENTE E DOS RECURSOS NATURAIS RENOVÁVEIS - IBAMA, 2005. Plano de manejo do parque Nacional da Serra da Canastra. Brasília: Ministério do Meio Ambiente.

KRABBE, N.K. and SCHULENBERG, T.S. 2019 [viewed 2 September 2019]. Brasilia Tapaculo (Scytalopus novacapitalis). In: J. DEL HOYO, A. ELLIOTT, J. SARGATAL, D.A. CHRISTIE and E. DE JUANA, eds. Handbook of the birds of the world alive. Barcelona: Lynx Edicions. Available from: https://www. hbw.com/node/ 56943

LIMA, W.P. and ZAKIA, M.J.B. 2004. Hidrologia de matas ciliares. In: R.R. RODRIGUES and H.F. LEITÃO-FILHO, eds. Matas ciliares: conservação e recuperação. 2. ed. São Paulo: Edusp, Fapesp, 320 p

MACHADO, T.L.S.S., LOMBARDI, V.T., DE MEIRELES, R.C., TEIXEIRA, J.P.G., SOLAR, R.R.C. and LOPES, L.E., 2017. Breeding biology of the threatened Campo Miner Geositta poeciloptera (Aves: Scleruridae), a neotropical grassland specialist. Journal of Natural History, vol. 51, no. 41-42, pp. 2551-2563. http://dx.doi.org/10.1080/00222933.2017.1381771.

MACKENZIE, D.I., NICHOLS, J.D., LACHMAN, G.B., DROEGE, S., ROYLE, J.A. and LANGTIMM, C.A., 2002. Estimating site occupancy rates when detection probabilities are less than one. Ecology, vol. 83, no. 8, pp. 2248-2255. http://dx.doi. org/10.1890/0012-9658(2002)083[2248:ESORWD]2.0.CO;2.

MAGALHÃES, S.R., LIMA, G.S. and RIBEIRO, G.A., 2011. Avaliação dos incêndios florestais ocorridos no Parque Nacional Da Serra Da Canastra - Minas Gerais. Cerne, vol. 18, no. 1, pp. 135-141. http://dx.doi.org/10.1590/S0104-77602012000100016.

MARION, W.R., O'MEARA, T.E. and MAEHR, D.S., 1981. Use of playback recordings in sampling elusive or secretive birds. Studies in Avian Biology, vol. 6, pp. 81-85.

MEDEIROS, M.B. and FIEDLER, N.C., 2004. Incêndios florestais no Parque Nacional da Serra da Canastra: desafios para a conservação da biodiversidade. Ciência Florestal, vol. 14, no. 2, pp. 157-168. http://dx.doi.org/10.5902/198050981815.

MISTRY, J., 1998. Fire in the Cerrado (savannas) of Brazil: an ecological review. Progress in Physical Geography, vol. 22, no. 4, pp. 425-448. http://dx.doi.org/10.1177/030913339802200401.

NAIMAN, R.J. and DÉCAMPS, H., 1997. The ecology of interfaces: riparian zones. Annual Review of Ecology and Systematics, vol. 28 , no. 1, pp. 621-658. http://dx.doi.org/10.1146/annurev. ecolsys.28.1.621.

OLIVEIRA, M.T., DAMASCENO-JUNIOR, G.A., POTT, A., PARANHOS FILHO, A.C., SUAREZ, Y.R. and PAROLIN, P., 2014. Regeneration of riparian forests of the Brazilian Pantanal under flood and fire influence. Forest Ecology and Management, vol. 331, pp. 256-263. http://dx.doi.org/10.1016/j.foreco.2014.08.011.

PIVELLO, V.R., 2011. The use of fire in the Cerrado and Amazonian Rainforests of Brazil: past and present. Fire Ecology, vol. 7, no. 1, pp. 24-39. http://dx.doi.org/10.4996/fireecology.0701024.
PUSEY, B.J. and ARTHINGTON, A.H., 2003. Importance of the riparian zone to the conservation and management of freshwater fish: a review. Marine and Freshwater Research, vol. 54, no. 1, pp. 1-16. http://dx.doi.org/10.1071/MF02041.

QUINTELA, F.M., SANTOS, M.B., OLIVEIRA, S.V., COSTA, R. and CHRISTOFF, A., 2010. Javalis e porcos ferais (Suidae, Sus scrofa) na Restinga de Rio Grande, RS, Brasil: ecossistemas de ocorrência e dados preliminares sobre impactos ambientais. Neotropical Biology and Conservation, vol. 5, no. 3, pp. 172-178. http://dx.doi.org/10.4013/nbc.2010.53.06.

REIS, M.G., 2015. Efeitos do fogo sobre assembleias de aves de Cerrado. São Carlos: Universidade Federal de São Carlos, 113 p. Tese de doutorado em Ciências.

REIS, M.G., FIEKER, C.Z. and DIAS, M.M., 2016. The influence of fire on the assemblage structure of foraging birds in grasslands of the Serra da Canastra National Park, Brazil. Anais da Academia Brasileira de Ciências, vol. 88, no. 2, pp. 891-901. http://dx.doi. org/10.1590/0001-3765201620150177. PMid:27192195.

SANO, E.E., ROSA, R., BRITO, J.L. and FERREIRA, L.G., 2010. Land cover mapping of the tropical savanna region in Brazil. Environmental Monitoring and Assessment, vol. 166, no. 1-4, pp. 113-124. http://dx.doi.org/10.1007/s10661-009-0988-4. PMid:19504057.

SICK, H., 1997. Ornitologia brasileira. Rio de Janeiro: Ed. Nova Fronteira.

SILVA, J.M.C. and BATES, J.M., 2002. Biogeographic patterns and conservation in the South American Cerrado: a Tropical Savanna Hotspot: The Cerrado, which includes both forest and savanna habitats, is the second largest South American biome, and among the most threatened on the continent. Bioscience, vol. 52, no. 3, pp. 225-234. http://dx.doi.org/10.1641/00063568(2002)052[0225:BPACIT]2.0.CO;2.

SILVEIRA, L.F., 1998. The birds of Serra da Canastra National Park and adjacent areas, Minas Gerais, Brazil. Cotinga, vol. 10, pp. 55-65.

SOUZA, R.O., FIEKER, C.Z., REIS, M.G., BRUNO, S.F., RIBEIRO, P.V. and CARVALHO, C.M.S., 2017. Estratégias de integração entre pesquisa e manejo do fogo no Parque Nacional da Serra da Canastra como parte do desenvolvimento de um Programa de Manejo Integrado do fogo. Biodiversidade Brasileira, vol. 6 , no. 2, pp. 205-219.

STUTCHBURY, B.J. and MORTON, E.S., 2008. Recent advances in the behavioral ecology of tropical birds. The Wilson Journal of Ornithology, vol. 120, no. 1, pp. 26-38. http://dx.doi. org/10.1676/07-018.1

VIELLIARD, J.M.E., 1990. Estudo bioacústico das aves do Brasil: o gênero Scytalopus. Ararajuba, vol. 1, pp. 5-18.

VREZEC, A. and BERTONCELJ, I., 2018. Territory monitoring of Tawny Owls Strix aluco using playback calls is a reliable population monitoring method. Bird Study, vol. 65, suppl. 1, S52-S62. http://dx.doi.org/10.1080/00063657.2018.1522527.

WEGE, D.C. and LONG, A.J., 1995. Key areas for threatened birds in the Neotropics. Cambridge: BirdLife International.

ZAR, J.H., 1999. Biostatistical analysis. Upper Saddle River: Prentice Hall, 663 p. 